\title{
Extreme long-distance dispersal of the lowland tropical rainforest tree Ceiba pentandra L. (Malvaceae) in Africa and the Neotropics
}

\author{
CHRISTOPHER W. DICK, ${ }^{*}+$ ELDREDGE BERMINGHAM,+MARISTERRA R. LEMES $\ddagger$ and \\ ROGERIO GRIBEL‡ \\ *Department of Ecology and Evolutionary Biology and Herbarium, University of Michigan, 830 North University Avenue, \\ Ann Arbor, MI 48109, USA, +Smithsonian Tropical Research Institute, Unit 0948 APO AA 34002-0948, USA, †Instituto Nacional \\ de Pesquisas da Amazônia (INPA), Laboratorio de Genetica e Biologia Reprodutiva de Plantas (LabGen), CP 478, CEP 69.011-970 \\ Manaus, AM Brazil
}

\begin{abstract}
Many tropical tree species occupy continental expanses of rainforest and flank dispersal barriers such as oceans and mountains. The role of long-distance dispersal in establishing the range of such species is poorly understood. In this study, we test vicariance hypotheses for range disjunctions in the rainforest tree Ceiba pentandra, which is naturally widespread across equatorial Africa and the Neotropics. Approximate molecular clocks were applied to nuclear ribosomal [ITS (internal transcribed spacer)] and chloroplast ( $p s b \mathrm{~B}-p s b \mathrm{~F}$ ) spacer DNA sampled from 12 Neotropical and five West African populations. The ITS $(N=5)$ and $p s b \mathrm{~B}-p s b \mathrm{~F}(N=2)$ haplotypes exhibited few nucleotide differences, and ITS and $p s b \mathrm{~B}-p s b \mathrm{~F}$ haplotypes were shared by populations on both continents. The low levels of nucleotide divergence falsify vicariance explanations for transatlantic and cross-Andean range disjunctions. The study shows how extreme long-distance dispersal, via wind or marine currents, creates taxonomic similarities in the plant communities of Africa and the Neotropics.
\end{abstract}

Keywords: community assembly, long-distance dispersal, molecular clocks, phylogeography, tropical trees, vicariance

Received 11 December 2006; revision accepted 5 March 2007

\section{Introduction}

The species richness of tropical rainforest plant communities has been well documented (Wallace 1878; Leigh et al. 2004). Until recently, however, little was known about the geographical ranges of most rainforest plant species. Comparisons of regional floras (Ruokolainen et al. 2005) and tree inventory plots from the Amazon basin (Pitman et al. 1999; Pitman et al. 2001) have shown that many rainforest plant species are widespread and flank biogeographical barriers such as oceans and mountains. In lowland Ecuador, for example, approximately $30 \%$ of the vascular plant species have populations on both slopes of the Andean cordilleras ( $N=1431$ disjunct species) (Jørgensen \& León-Yánez 1999), and in Panama up to $60 \%$ of the rainforest tree

Correspondence: Christopher W. Dick, Fax: (734) 763-0544; E-mail: cwdick@umich.edu species cross the Andes and are widespread in the Amazon basin (Dick et al. 2005).

There are also, remarkably, many taxonomic similarities between Neotropical and African rainforests (Gentry 1993) despite the passage of nearly 100 million years since the fragmentation of western Gondwana (Pitman et al. 1993). At least 110 angiosperm genera (from 53 families) and 108 species are restricted to Africa and tropical America (Thorne 1973), of which only 20-25 are weedy or are cultivated by humans. At the scale of two 50-ha forest inventory plots, more than 30 genera and several tree species are shared between rainforests of Ecuador and Cameroon (Pennington \& Dick 2004).

The discontinuous ranges of so many tropical rainforest tree species raise fundamental biogeographical questions. Are widespread species the 'weedy' components of rainforest floras most likely to disperse over geographical barriers, as suggested by Gentry (1982)? Or are widespread 


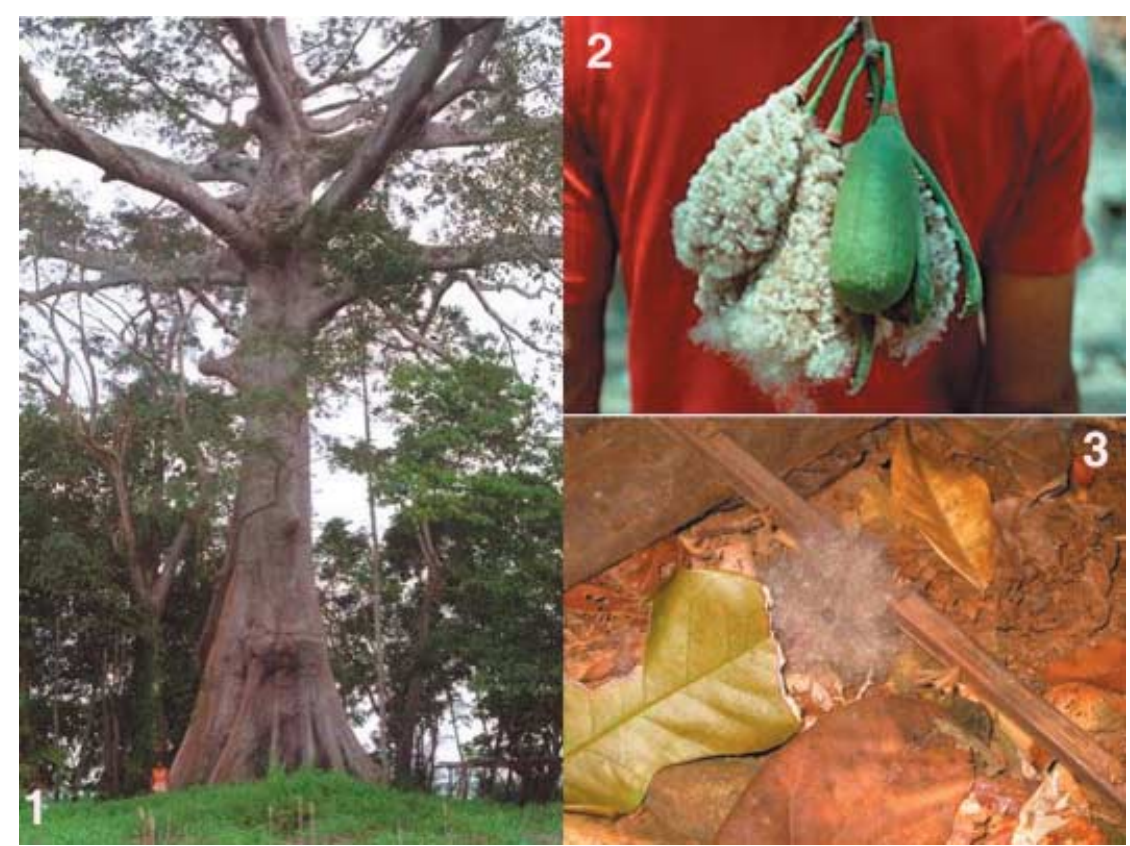

\begin{tabular}{lll}
\hline Rainforest form & Cultivated form & Savannah form \\
\hline Trunk spiny (prickles) & Trunk usually spineless & Trunk spineless \\
Buttress large & Buttress small & Buttress none \\
Branches horizontal & Branches ascending & Branches strongly ascending \\
Trunk straight & Trunk straight & Trunk often forked \\
Reproduction superannual & Reproduction annual & Reproduction annual \\
Leaves narrow & Leaves broader & Leaves broadest \\
Fruit capsule dehiscent & Fruit capsule indehiscent & Fruit capsule dehiscent \\
Chromosomes $2 n=80,88$ & $2 n=72-80$ (variable) & $2 n=72$ \\
\hline
\end{tabular}

Fig. 1 Ceiba pentandra clockwise from left (1) emergent Amazon tree with a person beside the characteristic buttress trunk (photo credit R. Gribel); (2) dehiscing fruit with kapok (photo credit A. Gentry); (3) seed enveloped in kapok (photo credit C. Dick).

Table 1 List of morphological and cytological character differences between three forms of Ceiba pentandra. Only the rainforest form (column 1) is found in Africa and Neotropics. The cultivated form, which shows intermediate features, is widely planted is Southeast Asia (modified from Table 1 in Baker 1965) species old members of rainforest communities, as suggested by vicariance models? Such questions have broad implications for ecology and evolution. For example, if $>30 \%$ of Ecuador's lowland flora evolved prior to the rise of the northern Andes, according to vicariance models (Jørgensen et al. 1999; Raven 1999), then conspecific populations of more than 1400 species have diverged in genetic isolation and without apparent morphological change for several million years, in a biome renowned for intense adaptive pressures (Dobzhansky 1950; Schemske 2002; Leigh et al. 2004).

In this study, we examined the biogeographical history of the widespread rainforest tree Ceiba pentandra L. (Fig. 1). Ceiba pentandra, also known as the kapok or silk-cotton tree, is widespread in the Neotropics (east and west of the Andes), and in equatorial Africa. We performed a phylogeographical analysis of C. pentandra using individuals sampled from throughout the natural geographical range. We then examined levels of $\mathrm{pDNA}$ and $\mathrm{nDNA}$ divergence to test vicariance hypotheses for the amphi-Atlantic and cross-Andean disjunctions.

\section{Ceiba pentandra L. Gaertner (Malvaceae)}

Neotropical C. pentandra L. is a buttressed, canopy-emergent tree that can grow to $70 \mathrm{~m}$ in height (Fig. 1). There are two distinctive natural forms of C. pentandra in Africa, and one hybrid. The rainforest form is a massive tree with a spiny trunk, as shown in Fig. 1. This is the only form found in the Neotropics and it is the focus of this study. The savanna form is restricted to West African savannas. It is a smaller tree, with a smooth trunk, and its reproductive timing does not coincide with that of the rainforest form. The cultivated form is a cross between the rainforest and savanna forms. The cultivated form has low branches and indehiscent fruits, which facilitate the harvest of kapok fibers used to stuff mattresses, pillows and life preservers. The cultivated form is widely planted outside of the parental species range (e.g. 'java kapok'), but has apparently not established natural populations (Baker 1965; Baker 1983). Under a more refined taxonomy, the savanna and rainforest forms might be classified as separate species based on numerous morphological and cytological differences (Table 1). 
Table 2 The observed $\left(K_{\mathrm{obs}}\right)$ and expected $\left(K_{\mathrm{exp}}\right)$ levels of nucleotide divergence between disjunct Ceiba pentandra populations is presented for ITS and cpDNA under as a test of vicariance hypotheses. The expectations are conservatively based on the slowest published rates of nucleotide substitution for ITS (Hamamelis), and the published rate for Adansonia, which is close to the mean of published ITS rates. The cpDNA expectations are based on slowest estimates for synonymous substitutions in the chloroplast genome. All values represent percentages of pairwise nucleotide divergence

\begin{tabular}{|c|c|c|c|c|c|c|}
\hline Vicariance event & Time $T$ & $\begin{array}{l}\text { ITS } K_{\exp } \\
\text { Hamamelis }\end{array}$ & $\begin{array}{l}\text { ITS } K_{\exp } \\
\text { Adansonia }\end{array}$ & $\begin{array}{l}\text { ITS } \\
K_{\text {obs }}\end{array}$ & $\begin{array}{l}\text { cpDNA } \\
K_{\exp }\end{array}$ & $\begin{array}{l}\text { cpDNA } \\
K_{\text {obs }}\end{array}$ \\
\hline Gondwana vicariance & $>96 \mathrm{ma}$ & $>7.30$ & $>54.91$ & $0-0.4$ & $>19.2$ & 0 \\
\hline Boreotropical dispersal & $>35 \mathrm{ma}$ & $>2.66$ & $>20.02$ & $0-0.4$ & $>7.0$ & 0 \\
\hline Andean uplift & $>3 \mathrm{ma}$ & $>0.23$ & $>1.72$ & 0 & $>0.6$ & $0-0.1$ \\
\hline
\end{tabular}

Ceiba pentandra (sensu lato) is one of nine species in the genus Ceiba. Ceiba is a member of the Malvacean subfamily Bombacoideae, which contains two Palaeotropical genera, Adansonia (Baobab trees) and Bombax, and seven Neotropical genera. Most authors have assumed a Neotropical origin of C. pentandra (Baker 1965; Gentry 1993; Baum et al. 2004) because the Neotropics harbours all Ceiba except the African populations of C. pentandra. Thorne (1973) suggested that 'often-cultivated plants (in Africa) like C. pentandra (L.) Gaertner may represent very early and intentional introductions by man'. In addition to morphological divergence within African Ceiba, however, two further lines of evidence indicate that Ceiba was not introduced into Africa by European traders: (i) fossil pollen of Ceiba occurs in 13000 years old deposits in Lake Bosumtwi in Ghana (Maley \& Livingstone 1983); and (ii) Arab trade of a cultivated form of C. pentandra from West Africa dates to the 10th century (Baker 1965).

The rainforest form of $C$. pentandra colonizes riverbanks and grows in both terra firme and floodplain habitats. It grows up to $2 \mathrm{~m}$ per year in open habitat and can set seed in as little as 2-6 years (Baker 1965). The dehiscent fruits (up to 30-cm long and 5-cm wide) contain large quantities of cottony kapok fibers, which entangle the small seeds as they are transported through wind and water (Fig. 1). A corky floating structure in the oily seed facilitates marine dispersal. During its flowering period, C. pentandra attracts bat and moth pollinators with nectar production in excess of $10 \mathrm{~L}$ per tree per night, or an estimated $200 \mathrm{~L}$ per flowering season (Gribel et al. 1999). Phyllostomid bats (Microchiroptera) pollinate Neotropical C. pentandra while pteropid bats (Megachiroptera) pollinate C. pentandra in Africa (Baker \& Harris 1959). Ceiba pentandra (sensu lato) is fully capable of self-fertilization (Baker 1965; Murawski \& Hamrick 1992; Lobo et al. 2005). Reproduction is limited to temperatures above $20^{\circ} \mathrm{C}$ during the flowering period (Baker 1965). Breeding populations are therefore restricted to tropical latitudes and to elevations $\leq 1500 \mathrm{~m}$ (Baker 1965).

\section{Vicariance models}

We evaluated two vicariance hypotheses for the amphiAtlantic disjunction: (i) Gondwana vicariance (ii) Boreotropical dispersal + vicariance (Table 2). Gondwana vicariance posits that the ancestor of an amphi-Atlantic taxon was widely distributed across the western Gondwana landmass prior to its separation into South America and Africa approximately 96 million years ago (Ma) (Pitman et al. 1993). The Boreotropical hypothesis references a warm phase in the Earth's climatic history (Eocene period; 54$35 \mathrm{Ma})$ during which time frost-intolerant (megathermal) vegetation occupied high latitudes ( $\leq 50$ degrees $N$ ), and crossed a land bridge between Europe and North America that disappeared in the late Oligocene (Tiffney 1985; Morley 2000; Davis et al. 2002). Both the Boreotropical and Gondwana vicariance hypotheses have been invoked to explain the amphi-Atlantic distribution of C. pentandra (Baker 1965). Low levels of nucleotide divergence (see molecular-clock methods) that correspond to $<<35 \mathrm{Ma}$ of genetic isolation would falsify both of these hypotheses.

The cross-Andean distribution of C. pentandra is also of biogeographical interest. The northern Andes of Ecuador, Colombia and Venezuela average more than $2000 \mathrm{~m}$ in elevation, while reproductive populations of $C$. pentandra are largely confined to elevations below $1500 \mathrm{~m}$. There are currently no contiguous populations of $C$. pentandra that span the Andes. Large error bars surround estimates of northern Andean palaeo-elevations (Gregory-Wodzicki 2000) but, in broad terms, the uplift of the northern cordilleras began in the early Miocene ( $24 \mathrm{Ma}$ ) and reached modern elevations $\geq 3 \mathrm{Ma}$ (Lundberg et al. 1998). To evaluate the hypothesis of cross-Andean vicariance, we anticipated genetic divergence corresponding to $\geq 3 \mathrm{Ma}$ of genetic isolation.

\section{Materials and methods}

\section{Collections}

Leaf material for DNA extraction was obtained from fresh leaves or herbarium specimens of rainforest Ceiba pentandra in West Africa (Cameroon $N=3$; Gabon $N=6$; Ghana $N=1$ ), Mesoamerica (Panama $N=4$; Costa Rica $N=4$; Mexico $N=1$ ) South America (Brazil, $N=18$; Ecuador, $N=12$; French Guiana, $N=2$ ) and the Caribbean (Puerto 


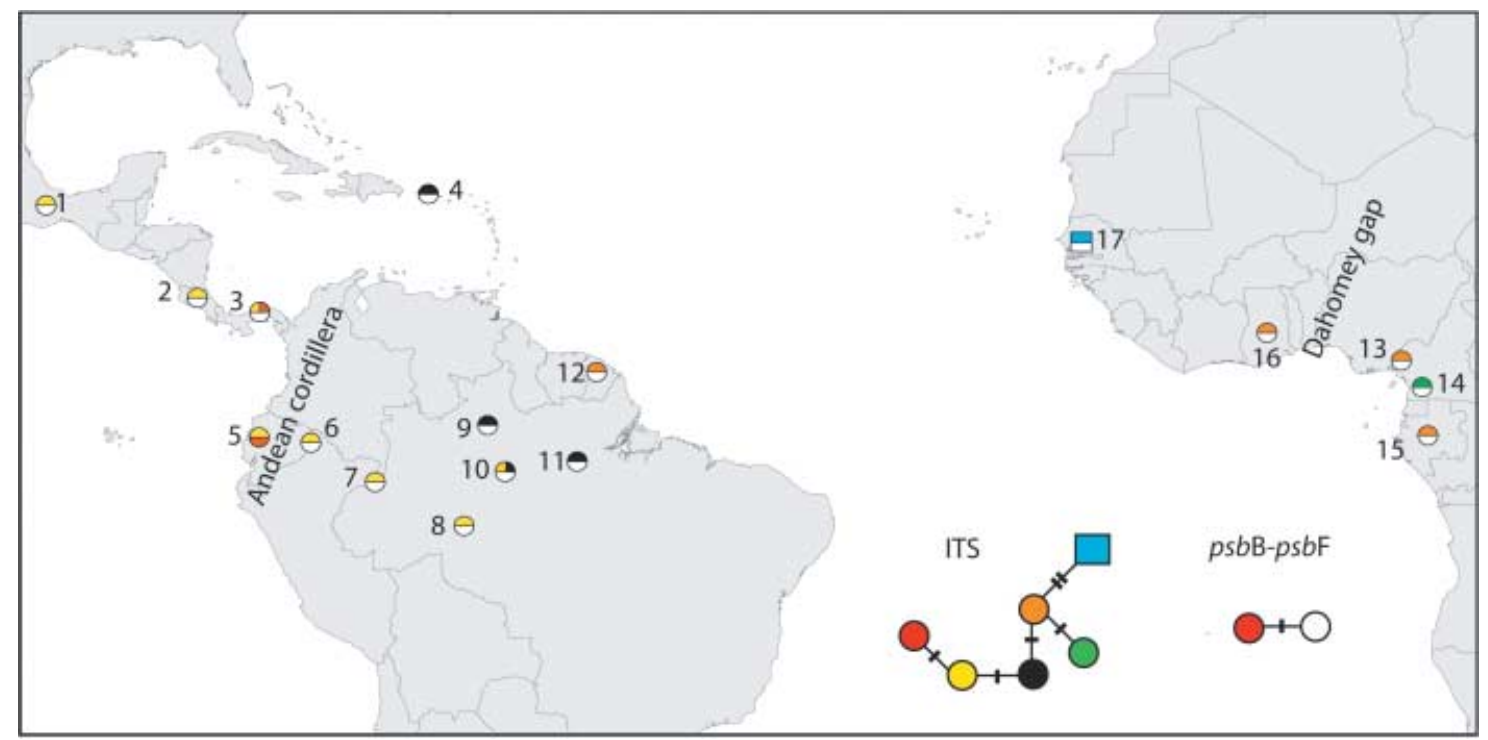

Fig. 2 Geographical distribution of ITS (upper semicircle) and $p s b \mathrm{~B}-p s b \mathrm{~F}$ (lower semicircle) haplotypes sampled from Neotropical and Western African Ceiba pentandra. The square haplotype (site 17, Senegal) represents the savanna form. Numbered collection sites correspond to column one in Table 3. Hatches correspond to numbers of nucleotide substitutions in the haplotype networks. Identical $p s b \mathrm{~B}-p s b \mathrm{~F}$ and ITS haplotypes across the Andes and between Africa and the Neotropics are evidence of long-distance dispersal.

Rico, $N=3$ ) (Fig. 2 and Table 3). We obtained a single collection of the savanna form from Senegal. Leaf sampling focused on adult trees separated by at least $100 \mathrm{~m}$, to avoid sampling of closely related individuals. Leaves were collected from massive individuals using slingshots. Most sampling within the sites designated in Fig. 2 spanned large distances. For example, sampling of trees in Panama (site 3) spanned approximately $200 \mathrm{~km}$; west Ecuador samples (site 5) spanned 80-100 km. Sampling within Gabon (site 15) spanned $300 \mathrm{~km}$. The overall Neotropical sampling spanned $5088 \mathrm{~km}$ (between Mexico and Rio Madeira, Brazil). The African sampling spanned $1655 \mathrm{~km}$ between sites in Senegal and Gabon and sampled Guinean and Congolese rainforest regions, which are separated by the arid Dahomey gap (Fig. 2). The DNA aliquot from each leaf sample was assigned a unique identification number (Laboratory ID), which is linked to information on geographical location, herbarium specimen number, or tag numbers in the case of trees sampled in permanent inventory plots.

\section{Laboratory methods}

DNA was extracted using the DNeasy kit (QIAGEN Corporation) following manufacturer protocols. The internal transcribed spacers ITS1 and ITS2 and the 5S ribosomal gene were amplified using the primers ITS4, ITS5 (White et al. 1990) and ITSi (Urbatsch et al. 2000), which anneal to the flanking $18 \mathrm{~S}$ and $26 \mathrm{~S}$ ribosomal genes. Chloroplast intergenic spacers were amplified using the $p s b \mathrm{~B}$ and $p s b \mathrm{~F}$ primers of Hamilton (1999a). Polymerase chain reactions (PCR) for ITS and $p s b \mathrm{~B}-p s b \mathrm{~F}$ were performed on an MJ Research thermal cycler with the following conditions: $94{ }^{\circ} \mathrm{C}$ for $4 \mathrm{~min}$, followed by 30 cycles of $94^{\circ} \mathrm{C}$ for $45 \mathrm{~s}$, $55^{\circ} \mathrm{C}$ for $45 \mathrm{~s}$ and $72{ }^{\circ} \mathrm{C}$ for $3 \mathrm{~min}$. Amplification products were extracted from low melting point agarose, cleaned up with Gelase (Epicentre Technologies), and sequenced using Big Dye chemistry [ABI (Applied Biosystems Incorporated)] on an ABI automated DNA sequencer. Chromatograms were aligned and edited with SEQUENCHER 4.1 (Gene Codes Corporation). All polymorphisms were confirmed by sequencing with forward and reverse primers. Absolute and maximum-likelihood (ML) genetic distances were calculated in PAUP ${ }^{*} 4.10 \mathrm{~b}$. The near complete lack of nucleotide divergence among haplotypes obviated the need for additional DNA sequence analyses.

\section{Substitution rates}

As there are no estimates of nucleotide substitution rates for Ceiba, we used an approximate molecular clock based on a broad range of published ITS and noncoding chloroplast DNA (cpDNA) nucleotide substitution rates. Estimated substitution rates for the ITS region (ITS1, 5.8S, and ITS2) range from 0.38 to $8.34 \times 10^{-9}$ substitutions per site per year (subs/site/year), based on surveys of 29 time-calibrated phylogenies of herbaceous and woody plant lineages drawn from 22 angiosperm families (reviewed in Richardson et al. 2001; Dick et al. 2003; Kay et al. 2006). The ITS rate estimate for Adansonia (Bombacoideae) of 
Table 3 Voucher information for sequenced individuals of Ceiba pentandra. The laboratory ID is a voucher number for the leaf tissue and DNA maintained at the University of Michigan. The GenBank Accession nos for $p s b \mathrm{~B}-p s b \mathrm{~F}$ and the ITS region are presented in the last two columns

\begin{tabular}{|c|c|c|c|c|c|}
\hline Map & Collection site & Coordinates & Laboratory ID & $p s b \mathrm{~B}-p s b \mathrm{~F}$ & ITS accession \\
\hline 4 & Camuy, Puerto Rico & $18^{\circ} 22^{\prime} \mathrm{N}, 66^{\circ} 45^{\prime} \mathrm{W}$ & 690 & DQ284781 & DQ284818 \\
\hline 4 & Camuy, Puerto Rico & $18^{\circ} 22^{\prime} \mathrm{N}, 66^{\circ} 45^{\prime} \mathrm{W}$ & 662 & $\mathrm{n} / \mathrm{a}$ & AY635499 \\
\hline 4 & Quebradillas, Puerto Rico & $18^{\circ} 22^{\prime} \mathrm{N}, 67^{\circ} 00^{\prime} \mathrm{W}$ & 663 & AY642683 & $\mathrm{n} / \mathrm{a}$ \\
\hline 4 & Quebradillas, Puerto Rico & $18^{\circ} 22^{\prime} \mathrm{N}, 67^{\circ} 00^{\prime} \mathrm{W}$ & 691 & DQ284782 & DQ284819 \\
\hline 1 & Morelos, Mexico & $18^{\circ} 51^{\prime} \mathrm{N}, 9^{\circ} 05^{\prime} \mathrm{W}$ & 1110 & DQ284783 & DQ284820 \\
\hline 2 & La Suerte, Costa Rica & $10^{\circ} 26^{\prime} \mathrm{N}, 83^{\circ} 46^{\prime} \mathrm{W}$ & 893 & $\mathrm{n} / \mathrm{a}$ & DQ284821 \\
\hline 2 & La Suerte, Costa Rica & $10^{\circ} 26^{\prime} \mathrm{N}, 83^{\circ} 46^{\prime} \mathrm{W}$ & 894 & DQ284784 & DQ284822 \\
\hline 2 & La Suerte, Costa Rica & $10^{\circ} 26^{\prime} \mathrm{N}, 83^{\circ} 46^{\prime} \mathrm{W}$ & 895 & DQ284785 & DQ284823 \\
\hline 2 & La Suerte, Costa Rica & $10^{\circ} 26^{\prime} \mathrm{N}, 83^{\circ} 46^{\prime} \mathrm{W}$ & 896 & $\mathrm{n} / \mathrm{a}$ & DQ284824 \\
\hline 2 & Jobero, Panama & $07^{\circ} 36^{\prime} \mathrm{N}, 80^{\circ} 33^{\prime} \mathrm{W}$ & 518 & AY642675 & AY635497 \\
\hline 2 & Jobero, Panama & $07^{\circ} 36^{\prime} \mathrm{N}, 80^{\circ} 33^{\prime} \mathrm{W}$ & 519 & AY642682 & AY635498 \\
\hline 3 & Jobero, Panama & $07^{\circ} 36^{\prime} \mathrm{N}, 80^{\circ} 33^{\prime} \mathrm{W}$ & 520 & DQ284786 & DQ284825 \\
\hline 3 & Naos Causeway, Panama & $08^{\circ} 55^{\prime} \mathrm{N}, 79^{\circ} 32^{\prime} \mathrm{W}$ & 879 & DQ284787 & DQ284826 \\
\hline 5 & Endesa reserve, Ecuador & $00^{\circ} 08^{\prime} \mathrm{N}, 79^{\circ} 03^{\prime} \mathrm{W}$ & 63 & $\mathrm{n} / \mathrm{a}$ & AY635495 \\
\hline 5 & Endesa reserve, Ecuador & $00^{\circ} 08^{\prime} \mathrm{N}, 79^{\circ} 03^{\prime} \mathrm{W}$ & 298 & AY642681 & AY635494 \\
\hline 5 & Borbon, Ecuador (km 29) & $01^{\circ} 05^{\prime} \mathrm{N}, 78^{\circ} 06^{\prime} \mathrm{W}$ & 867 & DQ284788 & DQ284827 \\
\hline 5 & Borbon, Ecuador (km 31) & $01^{\circ} 05^{\prime} \mathrm{N}, 78^{\circ} 06^{\prime} \mathrm{W}$ & 871 & DQ284789 & DQ284828 \\
\hline 5 & Borbon, Ecuador (km 10) & $01^{\circ} 05^{\prime} \mathrm{N}, 78^{\circ} 06^{\prime} \mathrm{W}$ & 875 & DQ284790 & DQ284829 \\
\hline 5 & Borbon, Ecuador (km 31) & $01^{\circ} 05^{\prime} \mathrm{N}, 78^{\circ} 06^{\prime} \mathrm{W}$ & 883 & DQ284791 & DQ284830 \\
\hline 6 & Yasuní park, Ecuador & $00^{\circ} 38^{\prime} \mathrm{S}, 76^{\circ} 30^{\prime} \mathrm{W}$ & 64 & DQ284792 & $\mathrm{n} / \mathrm{a}$ \\
\hline 6 & Yasuní park, Ecuador & $00^{\circ} 38^{\prime} \mathrm{S}, 76^{\circ} 30^{\prime} \mathrm{W}$ & 65 & DQ284793 & AY635500 \\
\hline 6 & Yasuní park, Ecuador & $00^{\circ} 38^{\prime} \mathrm{S}, 76^{\circ} 30^{\prime} \mathrm{W}$ & 66 & DQ284794 & AY635501 \\
\hline 6 & Yasuní park, Ecuador & $00^{\circ} 38^{\prime} \mathrm{S}, 76^{\circ} 30^{\prime} \mathrm{W}$ & 67 & DQ284795 & DQ284831 \\
\hline 6 & Yasuní park, Ecuador & $00^{\circ} 38^{\prime} \mathrm{S}, 76^{\circ} 30^{\prime} \mathrm{W}$ & 68 & DQ284796 & DQ284832 \\
\hline 6 & Yasuní park, Ecuador & $00^{\circ} 38^{\prime} \mathrm{S}, 76^{\circ} 30^{\prime} \mathrm{W}$ & 1021 & DQ284797 & DQ284833 \\
\hline 7 & Tabatinga, Brazil & $00^{\circ} 03^{\prime} \mathrm{S}, 69^{\circ} 40^{\prime} \mathrm{W}$ & 914 & AY642680 & DQ284834 \\
\hline 7 & Tabatinga, Brazil & $00^{\circ} 03^{\prime} \mathrm{S}, 69^{\circ} 40^{\prime} \mathrm{W}$ & 915 & DQ284798 & AY635493 \\
\hline 10 & Manaus, Brazil & $02^{\circ} 50^{\prime} \mathrm{S}, 59^{\circ} 49^{\prime} \mathrm{W}$ & 910 & AY642676 & DQ284835 \\
\hline 10 & Manaus, Brazil & $03^{\circ} 04^{\prime} \mathrm{S}, 60^{\circ} 00^{\prime} \mathrm{W}$ & 911 & AY642677 & DQ284836 \\
\hline 10 & Manaus, Brazil & $03^{\circ} 04^{\prime} \mathrm{S}, 59^{\circ} 50^{\prime} \mathrm{W}$ & 1088 & DQ284799 & AY635504 \\
\hline 10 & Manaus, Brazil & $03^{\circ} 04^{\prime} \mathrm{S}, 59^{\circ} 58^{\prime} \mathrm{W}$ & 1089 & DQ284800 & DQ284837 \\
\hline 10 & Manaus, Brazil & $03^{\circ} 12^{\prime} \mathrm{S}, 5^{\circ} 57^{\prime} \mathrm{W}$ & 1095 & DQ284801 & DQ284838 \\
\hline 9 & Caracaraí, Brazil (Rio Branco) & $01^{\circ} 36^{\prime} \mathrm{N}, 61^{\circ} 13^{\prime} \mathrm{W}$ & 916 & DQ284802 & DQ284839 \\
\hline 9 & Caracaraí, Brazil (Rio Branco) & $01^{\circ} 36^{\prime} \mathrm{N}, 61^{\circ} 13^{\prime} \mathrm{W}$ & 917 & DQ284803 & DQ284840 \\
\hline 9 & Caracaraí, Brazil (Rio Branco) & $01^{\circ} 36^{\prime} \mathrm{N}, 61^{\circ} 13^{\prime} \mathrm{W}$ & 1098 & $\mathrm{n} / \mathrm{a}$ & DQ284841 \\
\hline 11 & Castanhal Veado, Brazil (Rio Trombetas) & $01^{\circ} 18^{\prime} \mathrm{S}, 56^{\circ} 30^{\prime} \mathrm{W}$ & 918 & DQ284804 & DQ284842 \\
\hline 11 & Castanhal Veado, Brazil (Rio Trombetas) & $01^{\circ} 18^{\prime} \mathrm{S}, 56^{\circ} 30^{\prime} \mathrm{W}$ & 919 & DQ284805 & DQ284843 \\
\hline 11 & Castanhal Veado, Brazil (Rio Trombetas) & $01^{\circ} 18^{\prime} \mathrm{S}, 56^{\circ} 30^{\prime} \mathrm{W}$ & 1092 & DQ284806 & DQ284844 \\
\hline 11 & Castanhal Veado, Brazil (Rio Trombetas) & $01^{\circ} 18^{\prime} \mathrm{S}, 56^{\circ} 30^{\prime} \mathrm{W}$ & 1093 & DQ284807 & DQ284845 \\
\hline 8 & Remanso, Brazil (Rio Madeira) & $05^{\circ} 06^{\prime} \mathrm{S}, 59^{\circ} 27^{\prime} \mathrm{W}$ & 912 & DQ284808 & $\mathrm{n} / \mathrm{a}$ \\
\hline 8 & Remanso, Brazil (Rio Madeira) & $05^{\circ} 06^{\prime} \mathrm{S}, 59^{\circ} 27^{\prime} \mathrm{W}$ & 1091 & DQ284809 & DQ284846 \\
\hline 8 & Remanso, Brazil (Rio Madeira) & $05^{\circ} 06^{\prime} \mathrm{S}, 59^{\circ} 27^{\prime} \mathrm{W}$ & 913 & AY642679 & DQ284847 \\
\hline 12 & Kourou, French Guiana & $05^{\circ} 09^{\prime} \mathrm{N}, 52^{\circ} 39^{\prime} \mathrm{W}$ & 468 & DQ284810 & DQ284848 \\
\hline 12 & Kourou, French Guiana & $05^{\circ} 09^{\prime} \mathrm{N}, 52^{\circ} 39^{\prime} \mathrm{W}$ & 469 & DQ284811 & AY635496 \\
\hline 13 & Korup Park, Cameroon & $05^{\circ} 04^{\prime} \mathrm{N}, 08^{\circ} 51^{\prime} \mathrm{E}$ & 61 & AY642673 & AY635502 \\
\hline 13 & Korup Park, Cameroon & $05^{\circ} 04^{\prime} \mathrm{N}, 08^{\circ} 51^{\prime} \mathrm{E}$ & 62 & AY642674 & AY635503 \\
\hline 14 & Bimbia, Cameroon & $03^{\circ} 06^{\prime} \mathrm{N}, 09^{\circ} 16^{\prime} \mathrm{E}$ & 1101 & DQ284812 & DQ284849 \\
\hline 15 & Gabon (OH 91) & $02^{\circ} 34^{\prime} \mathrm{S}, 10^{\circ} 44^{\prime} \mathrm{E}$ & 1118 & DQ284813 & DQ284850 \\
\hline 15 & Gabon (OH 92) & $01^{\circ} 20^{\prime} \mathrm{S}, 13^{\circ} 07^{\prime} \mathrm{E}$ & 1119 & DQ284814 & DQ284851 \\
\hline 15 & Gabon (OH 93) & $00^{\circ} 99^{\prime} \mathrm{S}, 12^{\circ} 44^{\prime} \mathrm{E}$ & 1120 & DQ284815 & DQ284852 \\
\hline 15 & Gabon (OH 94) & $00^{\circ} 32^{\prime} \mathrm{N}, 11^{\circ} 27^{\prime} \mathrm{E}$ & 1121 & DQ284816 & DQ284853 \\
\hline 15 & Gabon (OH 95) & $00^{\circ} 50^{\prime} \mathrm{N}, 12^{\circ} 80^{\prime} \mathrm{E}$ & 1122 & DQ284817 & DQ284854 \\
\hline 15 & Gabon (OH 97) & $00^{\circ} 11^{\prime} \mathrm{S}, 11^{\circ} 59^{\prime} \mathrm{E}$ & 1124 & $\mathrm{n} / \mathrm{a}$ & DQ284855 \\
\hline 16 & Elmina, Ghana & $06^{\circ} 02^{\prime} \mathrm{N}, 01^{\circ} 04^{\prime} \mathrm{W}$ & 1199 & $\mathrm{n} / \mathrm{a}$ & EF432375 \\
\hline 17 & Oussouye, Senegal & $12^{\circ} 26^{\prime} \mathrm{N}, 16^{\circ} 45^{\prime} \mathrm{W}$ & 1200 & EF432373 & EF432374 \\
\hline
\end{tabular}

(C) 2007 The Authors

Journal compilation @ 2007 Blackwell Publishing Ltd 
$2.48 \times 10^{-9}$ subs/site/year (Baum et al. 1998) is close the mean rate of $2.86 \times 10^{-9}$ subs/site/year estimated by Kay et al. (2006). We compared the observed levels of divergence in disjunct C. pentandra with the Adansonia rate $\left(2.48 \times 10^{-9}\right.$ subs/site/year) and the slowest published ITS rate $\left(0.38 \times 10^{-9}\right.$ subs/site/year) in the Kay et al. (2006) survey, which is derived from a fossil-calibrated study of Hamamelis (Wen et al. 1999). By using the slowest published rate, our analysis is likely to overestimate divergence times, thereby favouring acceptance of vicariance hypotheses. The per-site substitution rates in Hamamelis and Adansonia correspond to 0.076 and $0.572 \%$ divergence/Ma, respectively. Expected levels of nucleotide divergence are derived from the relationship $K=R T / 2$, where $K$ is the nucleotide divergence between two sequences, $R$ is the rate of nucleotide substitution and $T$ is the divergence time.

There are no similar reviews for substitution rates in the $p s b \mathrm{~B}-p s b \mathrm{~F}$ cpDNA spacer. Therefore, we considered a broad range of synonymous substitution rates $\left(R_{\mathrm{S}}\right)$ published for angiosperm cpDNA: Wolfe et al. (1987) estimated a range of 1.0-3.0 $\times 10^{-9}$ substitutions per silent site per year (subs/silent-site/year) based on a comparison of eight chloroplast genes from monocots and dicots (divergence time $T=140 \mathrm{Ma}$ ) and from wheat and maize $(T=20-40 \mathrm{Ma})$. Zurawski \& Clegg (1987) calculated an $R_{\mathrm{S}}$ of $1.3 \times 10^{-9}$ subs/silent-site/year based on cpDNA divergence between spinach and tobacco. Xiang et al. (2000) estimated $R_{\mathrm{S}}$ of 1.02 to $1.42 \times 10^{-9}$ subs / silent-site/year for the $r b c L$ gene, based on fossil calibration of the Cornus phylogeny, and obtained similar estimates of $R_{\mathrm{S}}$ from 10 sister taxa (from 10 families) that display the same Asia/North America disjunction. We applied the slowest rates of synonymous substitution $\left(1.0 \times 10^{-9}\right.$ subs/silent-site/year) to $p s b \mathrm{~B}-p s b \mathrm{~F}$ as a con- servative test of the vicariance hypotheses. This corresponds to a divergence rate of $0.2 \% / \mathrm{Ma}$.

For the Hamamelis- and Adansonia-derived ITS rates, expected percentage of nucleotide divergence between disjunct ITS haplotypes are $>7.30$ and $>54.91$ under Gondwana vicariance, $>2.66$ and $>20.02$ under the Boreotropical model, and $>0.23$ and $>1.72$ for Andean vicariance. The expectations for $p s b \mathrm{~B}-p s b \mathrm{~F}$ are $>19.2$ under the Gondwana model, > 7.0 under the Boreotropical model, and $>0.6$ for Andean vicariance (Table 2 ).

\section{Results}

ITS sequences averaging $750 \mathrm{bp}$ were obtained for 51 individuals (Table 3). The ITS sequences were G-C biased (nucleotide frequencies: $\mathrm{A}=0.17, \mathrm{C}=0.32, \mathrm{G}=0.33$ and $\mathrm{T}=0.18)$. Five polymorphic sites were found among all ITS sequences, including a single nucleotide indel (site 141, Fig. 3). Several individuals from the Amazon basin were heterozygous at two ITS nucleotide sites (a G/T polymorphism at site 224; and a T/C polymorphism at site 299) as indicated by dual chromatogram peaks on both forward and reverse strands. Two of the five ITS haplotypes (haplotypes 1 and 4 in Fig. 3) were represented by single individuals from Panama (GenBank DQ284825) and Cameroon (DQ284849). DNA sequences from the $p s b \mathrm{~B}-$ $p s b \mathrm{~F}$ spacer were obtained from 49 individuals (Table 3) and averaged $742 \mathrm{bp}$ in length. The $p s b \mathrm{~B}-p s b \mathrm{~F}$ sequences displayed a T-A bias in base composition $(\mathrm{A}=0.30, \mathrm{C}=0.17$, $\mathrm{G}=0.19, \mathrm{~T}=0.34)$. A single polymorphic site $(\mathrm{T} / \mathrm{A}$ substitution at site 219) distinguished the western Ecuador cpDNA haplotype $(N=5)$ individuals from the widespread cpDNA haplotype (Fig. 2).

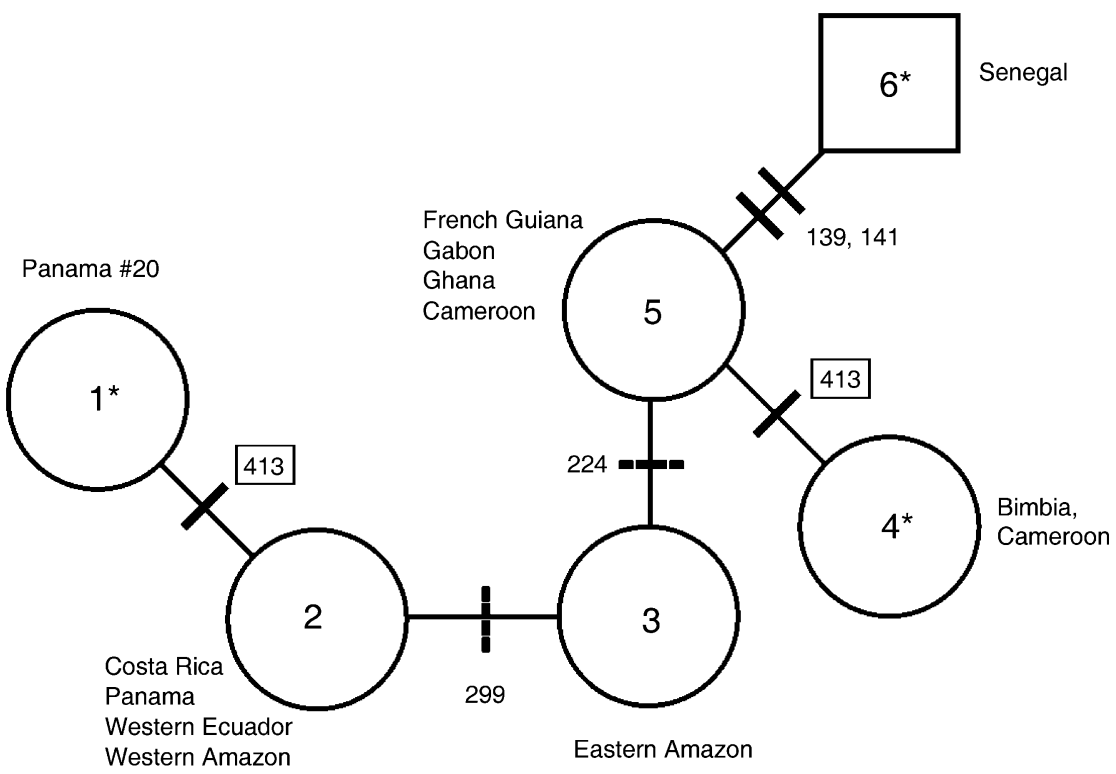

Fig. 3 Shallow phylogeographical structure of Ceiba pentandra is indicated by the ITS haplotype network (see also Fig. 2). Hatch marks indicate nucleotide changes at numbered positions in the consensus sequence. Sites 299 and 224, represented by dashed lines, were heterozygous in some individuals in Manaus. The substitution at site 413 is homoplasic in haplotypes 1 and 4 in this network. The squared haplotype is from the savanna form of C. pentandra. *represented by a single individual. 
Three individuals were excluded from the analysis because of anomalous ITS and $p s b \mathrm{~B}-p s b \mathrm{~F}$ sequences. Ecuador sample no. 66, collected from a juvenile tree, was divergent at both ITS (AY635501) and psbB-psbF (DQ284794) and was most likely collected from Ceiba saumauma, which has similar leaf morphology and is sympatric with Ceiba pentandra in lowland Ecuador. The ITS2 sequence of Puerto Rican sample no. 662 (AY635499) differed from the common haplotype by 14-bp differences, and it matched unpublished ITS sequence of Ceiba aesculus (K. Walsh, R. Oldham, and D. Baum, unpublished data). Gabon sample 1122 was highly divergent at ITS (DQ284854; > 83-bp differences or $\sim 13 \%$ nucleotide divergence), and its $p s b \mathrm{~B}-$ $p s b F$ sequence (DQ284817) differed from the widespread haplotype by three nucleotide changes. The Gabon ITS sequence matched the published ITS sequences of Bombax malabaricum (DQ826447 and AF460192).

The common $p s b \mathrm{~B}-p s b \mathrm{~F}$ haplotype was widespread in Africa and the Neotropics, and was also present in the savanna tree. An ITS haplotype was shared between populations in French Guiana and West Africa (Ghana, Cameroon and Gabon). The other ITS haplotypes found in Africa and the Neotropics differed by a maximum of four nucleotides (including one indel; $K=0.53 \%$ ). The ITS haplotype from the savanna tree from Senegal (EF432374) showed $0.3-0.6 \%$ divergence from the rainforest haplotypes. For reference, in a limited sample of six Ceiba species the level of interspecific ITS divergence varied from 2.8 (C. pentandra and C. crispifolia) to $6.0 \%$ (C. pentandra and C. aesculifolia) (K. Walsh, R. Oldham, and D. Baum, unpublished data), supporting the expected sister relationship between the rainforest and savannah forms of $C$. pentandra.

\section{Discussion}

Ceiba pentandra has the weakest phylogeographical structure yet reported for a widespread rainforest tree species. Apart from the cluster of sites in Western Ecuador having a variant $p s b \mathrm{~B}-p s b \mathrm{~F}$ haplotype, there was no cpDNA variation across Mesoamerica, the Amazon basin, and West Africa. In fact, this study found less cpDNA variation across three continents than some rainforest tree species exhibit within putative breeding populations in French Guiana and Brazil (Hamilton 1999b; Dutech et al. 2000; Latouche-Halle et al. 2003) or among sample sites at regional scales in French Guiana and across Mesoamerica (Caron et al. 2000; Cavers et al. 2003). Neotropical ITS haplotypes extended from Mexico into the Amazon basin, and the French Guiana ITS haplotype was encountered in multiple West African sites. The levels of divergence between distinct haplotypes across major range disjunctions fell below the vicariance expectations, even using the slowest published rates of cpDNA and ITS substitution (Table 2). These results falsify Gondwana vicariance, Boreotropical dispersal-vicariance, and Andean vicariance as applied to C. pentandra. Extreme long-distance dispersal, via wind or marine currents, appears to be the primary mode of geographical range expansion in C. pentandra.

\section{Oceanic dispersal}

Fossils and phylogeographical analysis of ITS in the amphi-Atlantic rainforest tree Symphonia globulifera (Clusiaceae) suggest that its populations invaded the Neotropics via oceanic dispersal at least once during the mid-Miocene, at which time Symphonia fossil pollen abruptly appears in Mesoamerica and South America. Despite a relatively slow estimated rate of nucleotide substitution in Symphonia ITS $\left(0.70 \times 10^{-9}\right.$ subs / site/year $)$, there was $>4 \%$ nucleotide divergence between African and Neotropical populations (Dick et al. 2003). As with Symphonia, most transatlantic plant dispersal is thought to proceed from Africa to the Neotropics (Renner 2004), with possible exceptions found in the genera Andira (Pennington 2003), Drepanocarpus, Hernandia, Hymenaea, Sacoglottis and Thalia (Renner 2004). The Neotropical origin of C. pentandra is supported by the Neotropical distribution of all recognized Ceiba species. Furthermore, there is a much higher level of divergence among the Neotropical species (e.g. $6.0 \%$ between $C$. pentandra and C. aesculifolia) than expected if African C. pentandra were the progenitor of a Neotropical radiation. Under the latter scenario, there should be $>6 \%$ divergence between African and Neotropical C. pentandra. The occurrence of identical ITS haplotypes in French Guiana and West Africa suggests recent dispersal to Africa from northern South America. Alternatively, the French Guiana haplotype may represent secondary dispersal from Africa.

Exceptionally strong winds between northeast Brazil and West Africa may have transported kapok-entangled seeds. Wind transport is a plausible explanation for the African range expansion of the Neotropical bromeliad Pitcairnia feliciana (Bromeliaceae), the herb Maschalocephalus dinklagei (Rapateaceae) (Givnish et al. 2004) and woody lineages of Melastomataceae (Renner \& Meyer 2001). Ceiba pentandra fruits and/or seeds could have floated to Africa as effluent from large Neotropical rivers (Houle 1998) such as the Amazon or Orinoco. Ceiba pentandra must have dispersed or transported by people to Puerto Rico, since this is a volcanic island that has never been connected to mainland (Iturralde-Vinent \& MacPhee 1999).

Ceiba pentandra is typically found in low population densities, but large individuals can produce hundreds of thousands of seeds. Rapid growth, longevity, the mixed mating system, and extensive seed and pollen dispersal all favour rapid colonization. Once a founding population has been established, wind dispersal of seeds and bat pollination along rivers may rapidly increase the size of breeding 
populations. In a microsatellite-based paternity analysis of C. pentandra along the Rio Negro in Brazil, Gribel and colleagues (referenced by Wilson et al. 1997) demonstrated bat-mediated pollen dispersal of nearly $20 \mathrm{~km}$ among spatially isolated trees. Assuming a Neotropical origin, the founding individuals in Africa could have lost recessive deleterious alleles through genetic drift. The genetic purge would result in less inbreeding depression and a lower rate of abortion of self-fertilized ovules (Hufford \& Hamrick 2003; Ward et al. 2005). In agreement with this model, Baker (1965) reported high levels of successful self-fertilization (up to 100\%) in Africa compared to South American C. pentandra.

\section{Ecological divergence}

Our study includes one Senegalese representative of the savanna form of $C$. pentandra. The ITS sequence in this sample differs by two nucleotides $(<0.3 \%)$ from the most similar rainforest haplotype (Fig. 2), and it shares the $p s b \mathrm{~B}-p s b \mathrm{~F}$ sequence found in African rainforest and most Neotropical samples. The savanna form probably derives from African populations of the rainforest form. It is possible, however, that the savanna form originated from Neotropical populations in a separate founder event. Testing for multiple founder events will require further geographical and genomic sampling.

Ceiba pentandra exhibits considerable morphological and cytological variation (Table 1), despite relatively low levels of nucleotide divergence. Chromosome counts of Neotropical $(2 n=88)$ and African rainforest trees $(2 n=80,88)$ are similar and may overlap. The African savanna form has a chromosome count of $2 n=72$, however, and chromosome counts for cultivated Ceiba are variable $(2 n=72,74,75,76$, 80) (Baker 1965). Savanna and rainforest forms differ in morphology of their leaves, flowers, trunk, and canopy architecture. The flowering periods are not synchronous, and both African forms (savanna and rainforest) have lost sulphuric compounds used to attract Microchiropteran bats (Pettersson et al. 2004). While this level of variation seems unusual in light of its recent origin, it should be noted that many plant taxa have experienced recent and rapid adaptive radiations. The species-rich tree genus Inga, for example, is comprised of nearly 300 Neotropical rainforest species that probably share a common ancestor less than 2 million years ago (Lavin 2006). Some closely related Inga species share identical ITS haplotypes (Richardson et al. 2001).

\section{Mountain crossings}

Although both many wind- and animal-dispersed rainforest tree species exhibit strong genetic differentiation around the Central American cordilleras (Cavers et al. 2003; Dick et al. 2003; Novick et al. 2003; Cavers et al. 2005) no such pattern was detected in C. pentandra. In South America, the C. pentandra population in coastal Ecuador contained a variant $p s b \mathrm{~B}-p s b \mathrm{~F}$ haplotype; but these same individuals shared widespread ITS haplotypes that provide evidence for dispersal over or around the northern Andes. In animals (Brower 1994; Zamudio \& Greene 1997; Slade \& Moritz 1998) and in the rainforest tree S. globulifera (Dick et al. 2003) levels of cross-Andean genetic divergence were consistent with Andean vicariance. However, some bats (Ditchfield 2000; Hoffmann \& Baker 2003), and euglossine bees (Dick et al. 2004) show the dispersal pattern found in C. pentandra. Further studies of lowland tree populations sampled from either side of the Andes will determine the extent to which cross-Andean communities have been genetically isolated. The present study nevertheless provides one exception to Raven's (1999) Andean vicariance hypothesis.

Some contemporary cross-Andean dispersal routes are possible. The Las Cruces mountain pass, for example, narrowly connects the Chocó region with the lowland Colombian Amazon via the Magdalena valley. Las Cruces is approximately $20-\mathrm{km}$ wide and $1874 \mathrm{~m}$ in elevation. While exceeding C. pentandra's altitudinal threshold for reproduction $(\leq 1500 \mathrm{~m})$, lowland tropical trees like $C$. pentandra may have reproduced and dispersed at higher altitudes during the mid-Holocene (6000 years before present), which was warmer $\left(1-4^{\circ} \mathrm{C}\right)$ and drier than present (Bush et al. 2004). A temperature increase of only $1{ }^{\circ} \mathrm{C}$ may increase the elevation of lowland rainforest species by more than $200 \mathrm{~m}$ (M. Bush, personal communication). Upwelling winds may also facilitate seed dispersal through mountain passes. Marine currents provide an alternative route; $C$. pentandra seeds could have reached the Caribbean coast of Mesoamerica via outflow of the Orinoco River, then dispersed over land through the Isthmus of Panama.

\section{Community assembly}

Long-distance dispersal has recently become an accepted biogeographical explanation for many amphi-Atlantic plant and animal disjunctions (de Queiroz 2004; Givnish \& Renner 2004; Pennington \& Dick 2004) and it may explain taxonomic similarities between rainforest tree communities. Pennington \& Dick (2004) evaluated the role of longdistance dispersal in structuring the community composition of trees in a 25-ha forest inventory plot in Yasuní, Ecuador (Valencia et al. 2004). 'Immigrants' were defined as species belonging to lineages that originated outside of South America long after its separation from Africa. The immigrant group included the Leguminosae (Schrire et al. 2004; Lavin et al. 2005), Annonaceae (Richardson et al. 2004), some lineages of Lauraceae (Chanderbali et al. 2001) and Melastomataceae s. str. (Renner et al. 2001). Of the 1104 tree species identified in the Yasuní forest, 232 (21\%) 
belonged to families and genera classified as immigrants. Some of the immigrant lineages may have arrived directly from Africa via marine dispersal, as in the case of S. globulifera, while others may have crossed the Panama land bridge. Summed over geological time, intercontinental migration and long-distance dispersal events contributed substantially to the taxonomic composition of a species-rich Amazon tree community. Thus, C. pentandra's dispersal and range expansion in Africa is a snapshot of a process that has created many other taxonomic similarities between rainforests throughout the world.

\section{Acknowledgements}

The collection of leaf samples from huge Ceiba trees scattered across the Neotropics and West Africa took several years, and we are indebted to many students and colleagues who have collaborated in the field and in the laboratory over this time period. Ivan Landires, Yaxelis Mendoza, Elsie Rivera-Ocasio, Susana Pereira and Carlos Vergara contributed in the laboratory. David Neill, Peggy Stern and Hugo Mogollón provided field assistance in Ecuador. Rick Condit, Catherine Woodward, Patrick Sweeney and Elsie Rivera-Ocasio generously provided Ceiba leaf samples. David Kenfack and Olivier Hardy provided nearly all of the African samples. David Baum, K. Walsh and R. Oldham allowed us to examine unpublished data. Egbert Leigh, Alan de Queiroz and three anonymous reviewers provided useful comments on the manuscript. The Smithsonian Tropical Research Institute (STRI), CIRAD-Fôret (French Guiana), the Instituto Nacional de Pesquisas da Amazônia (Brazil), Pontifica Universidad Católica de Ecuador, and ANAM (Panama) provided permits and/or access to collection sites. The project was funded by grants awarded to C. Dick from the International Plant Genetics Resource Institute, STRI, and the National Science Foundation (DEB 0640379). STRI visiting scholar fellowships to M. R. Lemes and R. Gribel facilitated this collaboration.

\section{References}

Baker HG (1965) The evolution of the cultivated kapok tree: a probable West African product. In: Ecology and Economic Development in Africa (ed. Brokensha D), pp. 185-217. Institute of International Studies, University of California, Berkeley, California.

Baker HG (1983) Ceiba pentandra (Ceyba, Ceiba, Kapok Tree). In: Costa Rican Natural History (ed. Janzen DH), pp. 212-214. University of Chicago Press, Chicago, Illinois.

Baker HG, Harris BJ (1959) Bat-pollination of the silk cotton tree, Ceiba pentandra (L.) Gaertn. (sensu lato), in Ghana. Journal of the West African Science Association, 4, 1-9.

Baum DA, Small RL, Wendel JF (1998) Biogeography and floral evolution of Baobabs (Adansonia, Bombacaceae), as inferred from multiple data sets. Systematic Biology, 47, 181-207.

Baum DA, Smith SD, Yen A et al. (2004) Phylogenetic relationships of Malvatheca (Bombacoideae and Malvoideae; Malvaceae sensu lato) as inferred from plastid DNA sequences. American Journal of Botany, 91, 1863-1871.

Brower AVZ (1994) Rapid morphological radiation and convergence among races of the butterfly Heliconius erato inferred from patterns of mitochondrial DNA evolution. Proceedings of the National Academy of Sciences, USA, 91, 6491-6495.

Bush MB, Silman MR, Urrego DH (2004) 48000 years of climate and forest change in a biodiversity hot spot. Science, 303, $827-$ 829.

Caron H, Dumas S, Marque G et al. (2000) Spatial and temporal distribution of chloroplast DNA polymorphism in a tropical tree species. Molecular Ecology, 9, 1089-1098.

Cavers S, Navarro C, Lowe AJ (2003) Chloroplast DNA phylogeography reveals colonization history of a Neotropical tree, Cedrela odorata L., in Mesoamerica. Molecular Ecology, 12, 1451-1460.

Cavers S, Navarro C, Hopkins P, Ennos RA, Lowe AJ (2005) Regional and population-scale influences on genetic diversity partitioning within Costa Rican populations of the pioneer tree Vochysia ferruginea Mart. Silvae Genetica, 54, 258-264.

Chanderbali AS, Van der Werff H, Renner SS (2001) Phylogeny and historical biogeography of Lauraceae: evidence from the chloroplast and nuclear genomes. Annals of the Missouri Botanical Garden, 88, 104-134.

Davis CC, Bell CD, Mathews S, Donoghue M (2002) Laurasian migration explains Gondwanan disjunctions: evidence from Malpighiaceae. Proceedings of the National Academy of Sciences, USA, 99, 6833-6837.

Dick CW, Abdul-Salim K, Bermingham E (2003) Molecular systematics reveals cryptic Tertiary diversification of a widespread tropical rainforest tree. American Naturalist, 162, 691-703.

Dick CW, Roubik DW, Gruber K, Bermingham E (2004) Long distance gene flow and cross-Andean dispersal of lowland rainforest bees (Apidae: Euglossini) revealed by comparative mtDNA phylogeography. Molecular Ecology, 13, 3775-3785.

Dick CW, Condit R, Bermingham E (2005) Biogeographic history and the high beta diversity of rainforest trees in Panama. In: The Rio Chagres: a Multidisciplinary Profile of a Tropical Watershed (ed. Harmon R), pp. 259-268. Springer Publishing Company, New York.

Ditchfield AD (2000) The comparative phylogeography of Neotropical mammals: patterns of intraspecific mitochondrial DNA variation among bats contrasted to nonvolant small mammals. Molecular Ecology, 9, 1307-1318.

Dobzhansky T (1950) Evolution in the tropics. American Scientist, 38, 208-221.

Dutech C, Maggia L, Joly HI (2000) Chloroplast diversity in Vouacapoua americana (Caesalpiniaceae), a Neotropical forest tree. Molecular Ecology, 9, 1427-1432.

Gentry A (1982) Neotropical floristic diversity: phytogeographical connections between Central and South America. Pleistocene climatic fluctuations or an accident of Andean orogeny? Annals of the Missouri Botanical Garden, 69, 557-593.

Gentry AH (1993) Diversity and floristic composition of lowland tropical forest in Africa and South America. In: Biological Relationships Between Africa and South America (ed. Goldblatt P), pp. 500-547. Yale University Press, New Haven, Connecticut.

Givnish TJ, Renner SS (2004) Tropical intercontinental disjunctions: Gondwana breakup, immigration from the boreotropics, and transoceanic dispersal. International Journal of Plant Sciences, 165, S1-S6.

Givnish TJ, Millam KC, Evans TM et al. (2004) Ancient vicariance or recent long-distance dispersal? Inferences about phylogeny and South American-African disjunctions in Rapateaceae and Bromeliaceae based on $\mathrm{ndhF}$ sequence data. International Journal of Plant Sciences, 165, S35-S54. 
Gregory-Wodzicki KM (2000) Uplift history of the central and northern Andes: a review. Geological Society of America Bulletin, 112, 1091-1105.

Gribel R, Gibbs P, Queiróz AL (1999) Flowering phenology and pollination biology of Ceiba pentandra (Bombacaceae) in Central Amazonia. Journal of Tropical Ecology, 15, 247-263.

Hamilton MB (1999a) Four primer pairs for the amplification of chloroplast intergenic regions with inraspecific variation. Molecular Ecology, 8, 513-525.

Hamilton MB (1999b) Tropical tree gene flow and seed dispersal. Nature, 401, 129-130.

Hoffmann FG, Baker RJ (2003) Comparative phylogeography of short-tailed bats (Carollia: Phyllostomidae). Molecular Ecology, 12, 3403-3414.

Houle A (1998) Floating islands: a mode of long-distance dispersal for small and medium-sized terrestrial vertebrates. Diversity and Distributions, 4, 201-216.

Hufford KM, Hamrick JL (2003) Viability selection at three early life stages of the tropical tree, Platypodium elegans (Fabaceae, Papilionoideae). Evolution, 57, 518-526.

Iturralde-Vinent MA, MacPhee RDE (1999) Paleogeography of the Caribbean Region: Implications for Cenozoic biogeography. Bulletin of the American Museum of Natural History, New York.

Jørgensen PM, León-Yánez S (1999) Catalogue of the Vascular Plants of Ecuador. Missouri Botanical Garden, St. Louis, Missouri.

Kay KM, Whitall JB, Hodges SA (2006) A survey of nuclear ribosomal internal transcribed spacer substitution rates across angiosperms: an approximate molecular clock with life history effects. BMC Evolutionary Biology, 6.

Latouche-Halle C, Ramboer A, Bandou E, Caron H, Kremer A (2003) Nuclear and chloroplast genetic structure indicate fine-scale spatial dynamics in a neotropical tree population. Heredity, 91, 181-190.

Lavin M (2006) Floristic and geographical stability of discontinuous seasonally dry tropical forests explains pattersn of plant phylogeny and endemism. In: Neotropical Savannas and Seasonally Dry Forests: Plant Diversity, Biogeography and Conservation (eds Pennington RT, Lewis GP, Ratter JA), pp. 433-447. CRC Press, Boca Raton, Florida.

Lavin M, Herendeen PS, Wojciechowski MF (2005) Evolutionary rates analysis of Leguminosae implicates a rapid diversification of lineages during the Tertiary. Systematic Biology, 54, 575-594.

Leigh EG, Davidar P, Dick CW et al. (2004) Why do some tropical forests have so many kinds of trees? Biotropica, 36, 447-473.

Lobo JA, Quesada M, Stoner KE (2005) Effects of pollination by bats on the mating system of Ceiba pentandra (Bombacaceae) populations in two tropical life zones in Costa Rica. American Journal of Botany, 92, 370-376.

Lundberg JG, Marshall LG, Guerrero J et al. (1998) The stage for Neotropical fish diversification: a history of tropical South American rivers. In: Phylogeny and Classification of Neotropical Fishes (eds Malabarba LR, Reis RE, Vari RP, Lucena SM, Lucena CAS), pp. 13-48. Edipucrs, Porto Alegre, Brazil.

Maley J, Livingstone DA (1983) Late Pleistocene and early Holocene extension of a mountain element in Southern Ghana (West Africa): Preliminary pollen data. Comptes Rendus de L'Academie des Sciences Serie II, 296, 1287-1292.

Morley RJ (2000) Origin and Evolution of Tropical Rain Forests. John Wiley \& Sons Ltd, West Sussex, UK.

Murawski DA, Hamrick JL (1992) Mating system and phenology of Ceiba pentandra (Bombacaceae) in central Panama. Journal of Heredity, 83, 401-404.
Novick RR, Dick C, Lemes MR et al. (2003) Genetic structure of Mesoamerican populations of Big-leaf mahogany (Swietenia macrophylla) inferred from microsatellite analysis. Molecular Ecology, 12, 2885-2893.

Pennington RT (2003) Monograph of Andira (LeguminosaePapilionoideae). Systematic Botany Monographs, 64, 1-143.

Pennington RT, Dick CW (2004) The role of immigrants in the assembly of the South American rainforest tree flora. Philosophical Transactions of the Royal Society of London. Series B, Biological Sciences, 359, 1611-1622.

Pettersson S, Ervik F, Knudsen JT (2004) Floral scent of batpollinated species: West Africa vs. the New World. Biological Journal of the Linnean Society, 82, 161-168.

Pitman WCI, Cande S, LaBreque J, Pindell J (1993) Fragmentation of Gondwana: the separation of Africa from South America. In: Biological Relationships Between Africa and South America (ed. Goldblatt P), pp. 202-213. Yale University Press, New Haven, Connecticut.

Pitman NCA, Terborgh J, Silman MR, Nuez P (1999) Tree species distributions in an upper Amazonian forest. Ecology, 80, 26512661.

Pitman NCA, Terborgh J, Silman MR et al. (2001) Dominance and distribution of tree species in upper Amazonian terra firme forests. Ecology, 82, 2101-2117.

de Queiroz A (2004) The resurrection of oceanic dispersal in historical biogeography. Trends in Ecology E Evolution, 20, 68-73.

Raven PH (1999) Foreward. In: Catalogue of the Vascular Plants of Ecuador (eds Jørgensen PM, León-Yánez S), pp. vi-viii. Missouri Botanical Garden, Saint Louis, Missouri.

Renner SS (2004) Plant dispersal across the tropical Atlantic by wind and sea currents. International Journal of Plant Science, 165, S23-S33.

Renner SS, Meyer K (2001) Melastomeae come full circle: biogeographic reconstruction and molecular-clock dating. Evolution, 55, 1315-1324.

Renner SS, Clausing G, Meyer K (2001) Historical biogeography of Melastomataceae: the roles of tertiary migration and longdistance dispersal. American Journal of Botany, 88, 1290-1300.

Richardson JE, Pennington RT, Pennington TD, Hollingsworth PM (2001) Rapid diversification of a species-rich genus of neotropical rain forest trees. Science, 293, 2242-2245.

Richardson JE, Chatrou LW, Mols JB, Erkens RHJ, Pirie MD (2004) Historical biogeography of two cosmopolitan families of flowering plants: Annonaceae and Rhamnaceae. Philosophical Transactions of the Royal Society of London. Series B, Biological Sciences, 359, 1495-1508.

Ruokolainen K, Tuomisto H, Kalliola R (2005) Landscape heterogeneity and species diversity in Amazonia. In: Tropical Rainforests: Past, Present and Future (eds Bermingham E, Dick CW, Moritz C), pp. 251-270. University of Chicago Press, Chicago, Illinois.

Schemske DW (2002) Ecological and evolutionary perspectives on the origins of tropical diversity. In: Foundations of Tropical Forest Biology (eds Chazdon RL, Whitmore TC), pp. 163-173. University of Chicago Press, Chicago, Illinois.

Schrire BD, Lavin M, Lewis GP (2004) Global distribution patterns of the Leguminosae: insights from recent phylogenies. In: Plant Diversity and Complexity Patterns - Local, Regional and Global Dimensions (eds Friis I, Balslev H). p. in press. Biologiske Skrifter, Copenhagen, Denmark.

Slade RW, Moritz C (1998) Phylogeography of Bufo marinus from its natural and introduced ranges. Proceedings of the Royal Society of London. Series B, Biological Sciences, 265, 769-777. 
Thorne RF (1973) Floristic relations between tropical Africa and tropical America. In: Tropical Forest Ecosystems in Africa and South America: A Comparative Review (eds Meggers B, Ayesu E, Duckworth W), pp. 27-47. Smithsonian Institution Press, Washington, D.C.

Tiffney BH (1985) The Eocene North Atlantic land bridge: its importance in Tertiary and modern phyotogeography of the northern hemisphere. Journal of the Arnold Arboretum, 66, 7394.

Urbatsch LE, Baldwin BG, Donoghue MJ (2000) Phylogeny of the coneflowers and relatives (Heliantheae: Asteraceae) based in nuclear rDNA internal transcribed spacer (ITS) sequences and chloroplast DNA restriction site data. Systematic Botany, 25, 539-565.

Valencia R, Foster RB, Villa G et al. (2004) Tree species distributions and local habitat variation in the Amazon: large forest plot in eastern Ecuador. Journal of Ecology, 92, 214-229.

Wallace AR (1878) Tropical Nature and Other Essays. Macmillan, New York and London.

Ward M, Dick CW, Gribel R, Lowe AJ (2005) To self, or not to self. A review of outcrossing and pollen-mediated gene flow in neotropical trees. Heredity, 95, 246-254.

Wen J, Shi S (1999) A phylogenetic and biogeographic study of Hamamelis (Hamamelidaceae), an eastern Asian and eastern North American disjunct genus. Biochemical Systematics and Ecology, $27,55-66$.

White TJ, Bruns T, Lee S, Taylor J (1990) Amplification and direct sequencing of fungal ribosomal RNA genes for phylogenetics. In: PCR Protocols: a Guide to Methods and Application (eds Innis M, Gelfand D, Sninsky J, White T), pp. 315-322. Academic Press, San Diego, California.

Wilson J, Lowe AJ, Cavers S et al. (1997) Assessment of levels and dynamics of intra specific genetic diversity of tropical trees: final scientific report. European Commission. 1-76.

Wolfe KH, Li W-H, Sharp PM (1987) Rates of nucleotide substitution vary greatly among plant mitochondrial, chloroplast, and nuclear DNAs. Proceedings of the National Academy of Sciences, USA, 84, 9054-9058.

Xiang QY, Soltis DE, Soltis PS, Manchester SR, Crawford DJ (2000) Timing the eastern Asian-Eastern North American floristic disjunction: molecular clock corroborates paleontological estimates. Molecular Phylogenetics and Evolution, 15, 462-472.

Zamudio KR, Greene HW (1997) Phylogeography of the bushmaster (Lachesis muta: Viperidae): implications for neotropical biogeography, systematics, and conservation. Biological Journal of the Linnean Society, 62, 421-442.

Zurawski GT, Clegg MT (1987) Evolution of higher-plant chloroplast DNA-encoded genes: implications for structure-function and phylogenetic studies. Annual Review of Plant Physiology, 38, 391-418.

Chris Dick is an assistant professor and curator at the University of Michigan, and a research associate at the Smithsonian Tropical Research Institute (STRI). Chris is interested in tropical forest history and the ecology, population structure and phylogeny of tropical trees. Biff Bermingham is a staff scientist and deputy director of STRI. Biff studies the diversification histories and community assembly of Neotropical fish, birds and other organisms. Rogério Gribel and Maristerra Lemes are researchers in Brazil's Institute for Amazon Research (INPA). Maristerra's main interests are population genetics, phylogeography and conservation of tropical trees. Rogério is interested in the genetics, reproductive biology and conservation of tropical trees. 